\title{
Aging of trivalent metal hydroxide/oxide gels in divalent metal salt solutions: Mechanism of formation of layered double hydroxides (LDHs)
}

\author{
A V RADHA and P VISHNU KAMATH* \\ Department of Chemistry, Central College, Bangalore University, Bangalore 560 001, India
}

MS received 9 May 2003; revised 2 September 2003

\begin{abstract}
While the aging of freshly precipitated $\mathrm{Al}(\mathrm{OH})_{3}$ gels in solutions of $\mathrm{Mg}$ and $\mathrm{Ni}$ salts leads to $\mathrm{LDH}$ formation at high (> 12) $\mathrm{pH}$, aging of ' $\mathrm{Fe}(\mathrm{OH})_{3}$ ' leads to $\mathrm{LDH}$ formation in $\mathrm{Mg}$ salt solutions but not in Ni salt 3 ' gels do not form LDHs on aging in any of the divalent metal salts. In general, conditions that promote the re-dissolution of the trivalent hydroxide also promote LDH formation showing that oxoanionic species such as $\mathrm{AlO}_{2}^{-}$have a role in $\mathrm{LDH}$ formation.
\end{abstract}

Keywords. Layered double hydroxides; pH metric titrations.

\section{Introduction}

Layered double hydroxides (LDHs) having the general formula, $\left[\mathrm{M}(\mathrm{II})_{1-x} \mathrm{M}^{\prime}(\mathrm{III})_{x}(\mathrm{OH})_{2}\right]\left(\mathrm{A}^{n-}\right)_{x / n} \cdot m \mathrm{H}_{2} \mathrm{O}$, are a class of compounds derived from the structure of mineral brucite, $\mathrm{Mg}(\mathrm{OH})_{2}$ (Cavani et al 1991). Brucite comprises a hexagonal packing of hydroxyl ions, in which $\mathrm{Mg}^{2+}$ ions occupy alternate layers of octahedral sites, leading to a stacking of charge-neutral layers having the composition $\left[\mathrm{Mg}(\mathrm{OH})_{2}\right]$ (Oswald and Asper 1977). When a fraction, $x$, of the $\mathrm{Mg}^{2+}$ ions is isomorphously substituted by trivalent ions, $\mathrm{M}^{\prime}(\mathrm{III})$ $\left(\mathrm{M}^{\prime}=\mathrm{Al}, \mathrm{Cr}, \mathrm{Fe}\right)$, the hydroxide layers acquire a positive charge with the composition, $\left[\mathrm{Mg}_{1-x} \mathrm{M}^{\prime}(\mathrm{III})_{x}(\mathrm{OH})_{2}\right]^{x+}$. Anions, $\mathrm{A}^{n-}$, are incorporated in the interlayer region for charge neutrality, resulting in the formation of LDHs. The interlayer distance in LDHs depends on the nature, size and orientation of the intercalated anion, $\mathrm{A}^{n-}$. It can vary from $7.6 \AA$ for carbonates to as high as $47 \AA$ for the vertical end-to-end bilayer arrangement of dodecylsulphate anions (Newman and Jones 1998). Many divalent ions such as $\mathrm{Ca}, \mathrm{Co}, \mathrm{Ni}, \mathrm{Cu}$ and $\mathrm{Zn}$ can take the place of $\mathrm{Mg}^{2+}$ (Carrado et al 1988) leading to a large family of compounds.

LDHs are of interest as they show many useful properties such as anionic mobility (Oesten and Böhm 1993), anion exchange (Newman and Jones 1998; Khan and O'Hare 2002), sorption (Miyata and Hirose 1978) and surface basicity (Constantino and Pinnavaia 1995), by virtue of which they are used as sensors, catalysts, electrodes (Kamath et al 1994) and as precursors to nanoparticulate oxides (Uzunova et al 1997). There is, therefore, a tremendous interest in the synthesis of these materials.

\footnotetext{
*Author for correspondence
}

Metal hydroxides are usually prepared by the addition of strong alkali to an appropriate metal salt solution according to the reaction

$$
\mathrm{M}_{n} \mathrm{~A}_{m}+n \times m \mathrm{NaOH} \rightarrow n \mathrm{M}(\mathrm{OH})_{m}+m \mathrm{Na}_{n} \mathrm{~A} .
$$

By extension, LDHs can be obtained by the coprecipitation from an appropriate mixed metal salt solution as

$$
\begin{array}{r}
(1-x) \mathrm{MA}_{2}+x \mathrm{M}^{\prime} \mathrm{A}_{3}+2 \mathrm{NaOH}+m \mathrm{H}_{2} \mathrm{O} \rightarrow \\
{\left[\mathrm{M}_{1-x} \mathrm{M}_{x}^{\prime}(\mathrm{OH})_{2}\right]\left(\mathrm{A}_{x}\right) \cdot m \mathrm{H}_{2} \mathrm{O}+2 \mathrm{NaA} .}
\end{array}
$$

A coprecipitation reaction can only succeed if the phases being coprecipitated have comparable solubility products. However, in the present instance, solubility products of the divalent hydroxides $\left(10^{-10}-10^{-16}\right)$ are several orders of magnitude higher than those of the trivalent metal hydroxides $\left(10^{-31}-10^{-38}\right)$ (Dobos 1975). Consequently addition of a strong alkali to a mixed metal salt solution is expected to lead to serial precipitation of the trivalent metal hydroxide followed by the divalent metal hydroxide rather than to the formation of $\mathrm{LDH}$.

However, the outcome of a precipitation reaction is affected by a number of factors (Grosso et al 1992), chief among them, being the $\mathrm{pH}$ at precipitation. This can be controlled by varying the sequence of addition of the reactants. By adding alkali to the metal salt solution, precipitation can be carried out at a low $\mathrm{pH}$. By adding the salt solution to an excess of strong alkali, precipitation can be carried out at a constant high pH. Reichle (1986) suggested that by using the latter technique, the solubility products of both the divalent as well as the trivalent metal hydroxides could be simultaneously exceeded facilitating their coprecipitation. This method is now widely used and a very large number of diverse LDHs such as those containing $\mathrm{Sc}^{3+}$ (Rousselot et al 2002), $\mathrm{V}^{3+}$ (Rives et al 1993), $\mathrm{Ga}^{3+}$ (Rebours et al 1994) and $\mathrm{In}^{3+}$ (Aramendía et al 1999) have been pre- 
pared.

Despite this general understanding, Boclair and coworkers (Boclair and Braterman 1998, 1999; Boclair et al 1999) in a series of papers, reported the formation of LDHs in $\mathrm{pH}$ metric titrations, involving the slow addition of $\mathrm{NaOH}$ to a mixed metal $\left(\mathrm{M}^{2+}+\mathrm{M}^{\prime 3+}\right)$ salt solution. Two $\mathrm{pH}$ plateaus were observed, the first corresponding to the precipitation of the trivalent hydroxide, ' $\mathrm{M}(\mathrm{OH})_{3}{ }^{3}$, followed by the second, which was attributed to LDH formation. By establishing equilibrium after each stage of alkali addition, Boclair and Braterman (1999) estimated the nominal solubility products and the formation constants of a large number of LDHs. These include the LDH of $\mathrm{Zn}$ with $\mathrm{Fe}$, which has not been reported to date and the LDHs of $\mathrm{Mg}$ and $\mathrm{Ni}$ with $\mathrm{Cr}$ (Boclair et al 1999) which are known to form only after prolonged hydrothermal treatment (Kooli et al 1995). Although the authors provide a table of $d$ spacings, no X-ray diffraction patterns have been provided, making it difficult to gauge the purity and crystallinity of the products obtained from the $\mathrm{pH}$ metric titrations.

The motivation for the present investigation is threefold: (i) to obtain solid state evidence for the formation of LDH during $\mathrm{pH}$ metric titrations by powder X-ray diffraction studies, (ii) to determine the mechanism by which the trivalent hydroxide, ' $\mathrm{M}$ ' $(\mathrm{OH})_{3}$ ' reacts with the divalent metal salt solution to yield the LDH and (iii) to determine if $\mathrm{pH}$ metric titrations do indeed lead to the formation of new LDHs that have not been reported so far.

\section{Experimental}

\section{1 pH metric titrations}

$250 \mathrm{ml}$ of mixed metal $\left(\mathrm{M}^{2+}+\mathrm{M}^{3+}\right)$ nitrate/chloride solu-

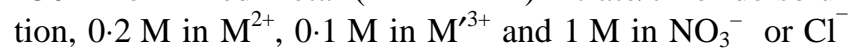
ions, was titrated $\mathrm{pH}$ metrically $(\mathrm{CD}$, India, $\mathrm{pH}$ meter, Alchemie gel filled electrode) against a $50 \% \mathrm{wt} / \mathrm{vol}$ $\mathrm{NaOH}$ solution with constant stirring. The $\mathrm{NaOH}$ solution was suitably diluted and standardized prior to each titration. The $\mathrm{NO}_{3}^{-} / \mathrm{Cl}^{-}$strength of $1 \mathrm{M}$ was attained by addition of the required quantity of $\mathrm{NaNO}_{3} / \mathrm{NaCl}$ to the mixed metal nitrate solution. The $\mathrm{NaOH}$ addition was done in steps of 0.1 to $0.5 \mathrm{ml}$ and the $\mathrm{pH}$ measured after the solution was allowed to equilibrate. The time required for the $\mathrm{pH}$ to achieve a constant value can be as high as $15 \mathrm{~min}$. The $\mathrm{pH}$ profiles of the titrations showed two plateau regions, which we refer to as I $\mathrm{pH}$ and II $\mathrm{pH}$. The values of $\mathrm{I} \mathrm{pH}$ and $\mathrm{II} \mathrm{pH}$ for all the systems investigated in this paper are given in table 1 .

The unary metal nitrates/chlorides were also titrated in separate experiments as controls. The anion strength was maintained at $1 \mathrm{M}$ in all cases, by the addition of $\mathrm{NaNO}_{3} /$ $\mathrm{NaCl}$. The $\mathrm{pH}$ profiles of these titrations showed a single plateau, on account of the precipitation of the correspond- ing unary hydroxides. The $\mathrm{pH}$ values of these plateaus are listed in table 2.

For solid state characterization, a small amount of the solid was removed from the reaction mixture when $92 \%$ of the stoichiometric requirement of $\mathrm{NaOH}$ had been dispensed (Boclair and Braterman 1999). At this point the $\mathrm{pH}$ of the reaction mixture was in the region of the second plateau. The titration was then continued up to a final $\mathrm{pH}$ of 12. The solid was then filtered and copiously washed, till the wash turned neutral. The solids obtained at both stages were analysed by powder X-ray diffraction (PXRD) and infrared spectroscopy.

\subsection{Aging experiments}

To test the hypothesis (Boclair and Braterman 1999) that LDH formation takes place by the reaction of solid ' $\mathrm{M}^{\prime}(\mathrm{OH})_{3}$ ' with the divalent metal salt in solution, stoichiometric quantities of freshly precipitated ' $\mathrm{Al}(\mathrm{OH})_{3}$ ', ' $\mathrm{Fe}(\mathrm{OH})_{3}$ ' and ' $\mathrm{Cr}(\mathrm{OH})_{3}$ ' were aged in a solution, $0 \cdot 2 \mathrm{M}$ in the divalent metal ion and $1 \mathrm{M}$ in $\mathrm{NaNO}_{3}$ or $\mathrm{NaCl}$. After ' $\mathrm{M}^{\prime}(\mathrm{OH})_{3}$ ' was suspended in this solution, the $\mathrm{pH}$ of the suspension was raised to the value of the II $\mathrm{pH}$ for the corresponding system by the addition of $\mathrm{NaOH}$. In separate experiments, the aging was also carried out at $\mathrm{pH}>12$. The aging was carried out under constant stirring for up to 6 days at the ambient temperature $\left(26-28^{\circ} \mathrm{C}\right)$. The

Table 1. $\mathrm{pH}$ values of first and second plateaus in $\mathrm{pH}$ titration profiles of mixed metal $\left(\mathrm{M}^{2+}+\right.$ $\mathrm{M}^{\prime 3+}$ ) salt systems.

\begin{tabular}{llc}
\hline $\mathrm{M}(\mathrm{II})-\mathrm{M}(\mathrm{III})$ & $\mathrm{I} \mathrm{pH}$ & $\mathrm{II} \mathrm{pH}$ \\
\hline $\mathrm{Mg}-\mathrm{Al}-\mathrm{Cl}$ & $3 \cdot 6$ & $7 \cdot 5$ \\
$\mathrm{Ni}-\mathrm{Al}-\mathrm{NO}_{3}$ & $3 \cdot 6$ & $6 \cdot 3$ \\
$\mathrm{Zn}-\mathrm{Al}-\mathrm{NO}_{3}$ & $3 \cdot 65$ & $\sim 5 \cdot 9$ \\
$\mathrm{Mg}-\mathrm{Fe}-\mathrm{Cl}$ & $1 \cdot 86$ & $9 \cdot 2$ \\
$\mathrm{Ni}-\mathrm{Fe}-\mathrm{Cl}$ & $1 \cdot 85$ & $7 \cdot 2$ \\
$\mathrm{Zn}-\mathrm{Fe}-\mathrm{NO}$ & $1 \cdot 85$ & $6 \cdot 0$ \\
$\mathrm{Ni}-\mathrm{Cr}-\mathrm{Cl}$ & $3 \cdot 4 *$ & - \\
\hline
\end{tabular}

*This system shows only one plateau.

Table 2. $\mathrm{pH}$ values of the plateaus observed during $\mathrm{pH}$ metric titrations of unary metal salt solutions with $\mathrm{NaOH}$ and the corresponding $\mathrm{p} K_{\mathrm{sp}}$ values.

\begin{tabular}{lccc}
\hline Hydroxide & $\begin{array}{c}\text { Plateau } \\
(\mathrm{pH})\end{array}$ & $\begin{array}{c}\mathrm{p} K_{\mathrm{sp}} \\
(\text { expt })\end{array}$ & $\begin{array}{c}\mathrm{p} K_{\mathrm{sp}} \\
\text { (literature value) }\end{array}$ \\
\hline $\mathrm{Al}(\mathrm{OH})_{3}$ & $3 \cdot 7$ & 31.9 & 32.72 \\
$\mathrm{Cr}(\mathrm{OH})_{3}$ & 3.6 & 31.9 & $30 \cdot 17$ \\
$\mathrm{Fe}(\mathrm{OH})_{3}$ & 1.9 & 37.3 & 37.42 \\
$\mathrm{Mg}(\mathrm{OH})_{2}$ & $9 \cdot 2$ & $10 \cdot 3$ & 11.26 \\
$\mathrm{Ni}(\mathrm{OH})_{2}$ & 7.2 & 14.3 & 13.79 \\
$\mathrm{Zn}(\mathrm{OH})_{2}$ & 5.9 & 16.9 & 16.69 \\
\hline
\end{tabular}


solids obtained in both experiments were analysed by PXRD and infrared spectroscopy. ' $\mathrm{Al}(\mathrm{OH})_{3}$ ', ' $\mathrm{Fe}(\mathrm{OH})_{3}$ ' and $\mathrm{C} \mathrm{C}(\mathrm{OH})_{3}$ ' were obtained by ammonia precipitation from the corresponding salt solutions. The resulting gelatinous precipitates were washed copiously with water to remove excess ammonia. The slurries were then used as such without drying.

All powder X-ray diffraction patterns were recorded using a JEOL Model JDX8P powder X-ray diffractometer ( $\mathrm{Co} \mathrm{K} \alpha$ source, $\lambda=1.79 \AA$ ). The PXRD patterns were indexed on hexagonal cells (see table 3 ). Infrared spectra were obtained using a Nicolet Model Impact 400D FTIR spectrometer ( $\mathrm{KBr}$ pellets, $4 \mathrm{~cm}^{-1}$ resolution).

\section{Results and discussion}

Titrations of unary metal salt solutions exhibit a single $\mathrm{pH}$ plateau corresponding to the precipitation of the corresponding hydroxide according to reaction (1). Expectedly the trivalent metals precipitate at a much lower $\mathrm{pH}$ than the divalent metals (table 2$)$. The solubility products $\left(\mathrm{p} K_{\mathrm{sp}}\right)$ calculated by the method of Boclair and Braterman (1999) from the $\mathrm{pH}$ values match well with those reported in the literature (Dobos 1975) (table 2). PXRD patterns showed all trivalent 'hydroxides' investigated here to be X-ray amorphous. This is not surprising in the case of $\mathrm{Cr}^{3+}$ and $\mathrm{Fe}^{3+}$, since these are known to form hydrous oxide gels of type, $\mathrm{M}_{2} \mathrm{O}_{3} \cdot n \mathrm{H}_{2} \mathrm{O}$. However, for convenience, these will be referred to as ' $\mathrm{M}^{\prime}(\mathrm{OH})_{3}$ '. $\mathrm{Al}(\mathrm{OH})_{3}$ is known to crystallize in two polymorphic modifications, bayerite and gibbsite (Wells 1979), but under conditions employed here only X-ray amorphous products were obtained.

PXRD investigations showed that the solid obtained from a $\mathrm{Mg}\left(\mathrm{NO}_{3}\right)_{2}$ solution was $\mathrm{Mg}(\mathrm{OH})_{2}$ (Radha et al 2003), from $\mathrm{Ni}\left(\mathrm{NO}_{3}\right)_{2}$ it was $\beta-\mathrm{Ni}(\mathrm{OH})_{2}$ (Ramesh et al 2003) and from $\mathrm{Zn}\left(\mathrm{NO}_{3}\right)_{2}$ it was $\mathrm{Zn}_{5}(\mathrm{OH})_{8}\left(\mathrm{NO}_{3}\right)_{2} \cdot 2 \mathrm{H}_{2} \mathrm{O}$ (this work).

Titrations of mixed metal $\left(\mathrm{M}^{2+}+\mathrm{M}^{3+}\right)$ salt solutions yielded a $\mathrm{pH}$ profile with two plateaus. In all cases the $\mathrm{I} \mathrm{pH}$ value coincided exactly with the $\mathrm{pH}$ at which the corres-

Table 3. Cell parameters of LDHs obtained by aging as well as $\mathrm{pH}$ metric titration.

\begin{tabular}{|c|c|c|c|}
\hline & \multirow[b]{2}{*}{ Method } & \multicolumn{2}{|c|}{ Cell parameters } \\
\hline & & $c(\AA)$ & $a(\AA)$ \\
\hline MgAlCl LDH & Aging at $\mathrm{pH}>12$ & $23 \cdot 0$ & $3 \cdot 04$ \\
\hline $\mathrm{MgAlCl} \mathrm{LDH}$ & During titration & $23 \cdot 2$ & $3 \cdot 04$ \\
\hline $\mathrm{MgFeCl} \mathrm{LDH}$ & Aging at $\mathrm{pH}=9.27$ & $23 \cdot 2$ & $3 \cdot 10$ \\
\hline $\mathrm{MgFeCl} \mathrm{LDH}$ & During titration & $23 \cdot 7$ & - \\
\hline ZnAlCl LDH & Before completion of titration & $26 \cdot 6$ & $3 \cdot 06$ \\
\hline ZnAlCl LDH & After completion of titration & $22 \cdot 9$ & $3 \cdot 06$ \\
\hline ZnAlCl LDH & Aging at $\mathrm{pH}=5 \cdot 6$ & $26 \cdot 1$ & $3 \cdot 06$ \\
\hline $\mathrm{ZnAlCl} \mathrm{LDH*}$ & Aging at $\mathrm{pH}>12$ & $22 \cdot 7$ & 3.06 \\
\hline
\end{tabular}

*Peaks due to $\mathrm{ZnO}$ impurities were also present. ponding trivalent hydroxide precipitates showing that the first plateau is due to the precipitation of ' $\mathrm{M}^{\prime}(\mathrm{OH})_{3}$ '. These observations are consistent with those made by Boclair and Braterman (1999). However, in contrast with the claims of Boclair and Braterman (1999), the II pH value is not always less than the $\mathrm{pH}$ at which the corresponding divalent hydroxide precipitates. The results are therefore discussed case by case.

\section{$3.1 M(I I)-A l(I I I)(M=M g, N i)$ systems}

Figure 1 compares the $\mathrm{pH}$ profile of the titration of a mixed metal $(\mathrm{Mg}+\mathrm{Al})$ chloride solution with the profiles of the titrations of the individual metal chlorides. The II $\mathrm{pH}$ value is 1.7 units less than the $\mathrm{Mg}(\mathrm{OH})_{2}$ precipitation $\mathrm{pH}$ showing that the solid precipitated at this plateau is not $\mathrm{Mg}(\mathrm{OH})_{2}$. PXRD pattern of the solid isolated from the reaction mixture at this stage reveals the formation of LDH ( $a=3.04 \AA ; c=23.19 \AA$ ) (figure $2 \mathrm{a}$ ), which is characterized by the presence of a low angle reflection at $7.73 \AA$ followed by another at $3.84 \AA$. $\mathrm{Mg}(\mathrm{OH})_{2}$ on the other hand has a basal spacing of only $4.77 \AA(a=3.147 \AA ; c=4.769$ $\AA$ ) (PDF: 7-239) (Smith 1967). Braterman and Boclair (1999) have suggested that LDH formation at the II pH value takes place due to a reaction between solid $\mathrm{Al}(\mathrm{OH})_{3}$ and dissolved $\mathrm{MgCl}_{2}$. To verify this hypothesis, freshly precipitated $\mathrm{Al}(\mathrm{OH})_{3}$ was aged in a solution of $\mathrm{MgCl}_{2}$ at a $\mathrm{pH}$ equal to the II $\mathrm{pH}$ value. Prolonged aging failed to yield LDH (figure 2c), showing that the second plateau observed during the titration is not due to $\mathrm{LDH}$ formation. However, aging $\mathrm{Al}(\mathrm{OH})_{3}$ at $\mathrm{pH}>12$, yielded the $\mathrm{LDH}$ (figure 2b).

Similar results were found in the $\mathrm{Ni}-\mathrm{Al}$ system as well (data not shown). Titration yielded the Ni-Al LDH. Aging solid $\mathrm{Al}(\mathrm{OH})_{3}$ in a nickel nitrate solution at the II $\mathrm{pH}$ value (6.3) did not lead to LDH formation, while the aging experi-

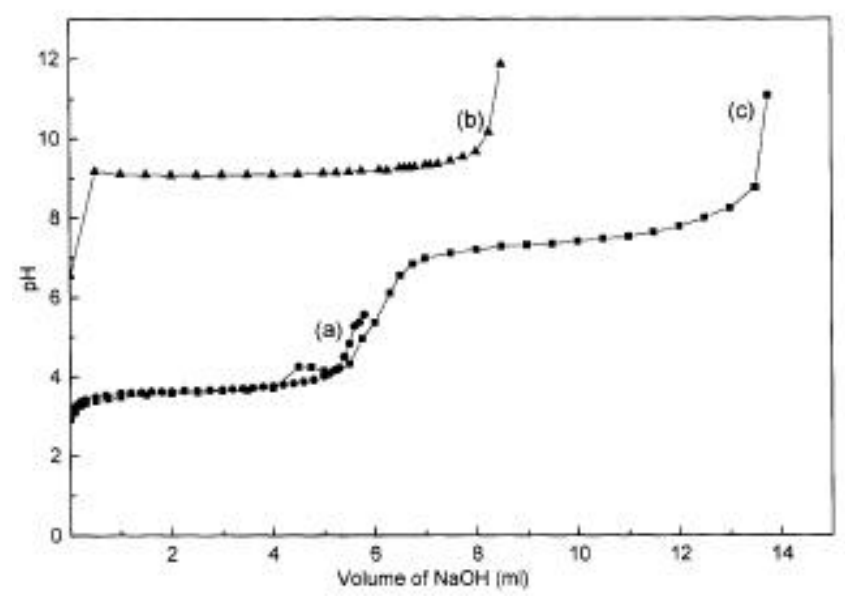

Figure 1. $\mathrm{pH}$ profiles of titrations of (a) an $\mathrm{AlCl}_{3}$ solution, (b) a $\mathrm{MgCl}_{2}$ solution compared with that of the (c) mixed metal $(\mathrm{Mg}+\mathrm{Al})$ chloride solution with $\mathrm{NaOH}$. 
ment carried out at $\mathrm{pH}>12$ led to the formation of the $\mathrm{Ni}-\mathrm{Al}$ LDH.

These observations throw open the following questions: (i) what is the second $\mathrm{pH}$ plateau due to? (ii) why is LDH formation observed during the titrations? (iii) why is LDH formation observed in aging experiments carried out at high (> 12) $\mathrm{pH}$ but not at the II $\mathrm{pH}$ value?

We offer the following explanation.

$\mathrm{Al}(\mathrm{OH})_{3}$ is amphoteric and as the $\mathrm{pH}$ is raised much above the $\mathrm{I} \mathrm{pH}$ value, it begins to redissolve according to the reaction

$$
\mathrm{Al}(\mathrm{OH})_{3}+\mathrm{OH}^{-} \Leftrightarrow \mathrm{AlO}_{2}^{-}+2 \mathrm{H}_{2} \mathrm{O} .
$$

The rapid consumption of $\mathrm{OH}^{-}$ions during this process is perhaps responsible for the II $\mathrm{pH}$ plateau. This occurs at a $\mathrm{pH}$ below that required for $\mathrm{Mg}(\mathrm{OH})_{2}$ precipitation. $\mathrm{LDH}$ formation then takes place by the reaction between dissolved species as

$$
\mathrm{AlO}_{2}^{-}+2 \mathrm{H}_{2} \mathrm{O}+2 \mathrm{M}^{2+}+2 \mathrm{OH}^{-}+\mathrm{Cl}^{-} \Leftrightarrow \mathrm{M}_{2} \mathrm{Al}(\mathrm{OH})_{6} \mathrm{Cl}
$$

A continuous supply of $\mathrm{OH}^{-}$ions is provided during titrations. $\mathrm{LDH}$ formation during titrations is therefore a result of kinetic rather than thermodynamic control. A similar situation exists during aging experiments carried out at high $(>12) \mathrm{pH}$, but not at low $\mathrm{pH}$. Establishment of an equilibrium between the $\mathrm{Mg}-\mathrm{Al} \mathrm{LDH}$ and the products of its dissolution has been reported to take a time in excess of 100 days (Johnson and Glasser 2003). The method of Johnson and Glasser (2003) in our opinion is the best for the estimation of the solubility products of LDHs.

\section{$3.2 M(I I)-F e(I I I)(M=M g, N i)$ systems}

Contrary to the claims of Boclair and Braterman (1999), the II $\mathrm{pH}$ value in all $\mathrm{Fe}$ containing systems was found to be exactly equal to the $\mathrm{pH}$ at precipitation of the unary divalent hydroxide (tables 1 and 2). We show in figure 3

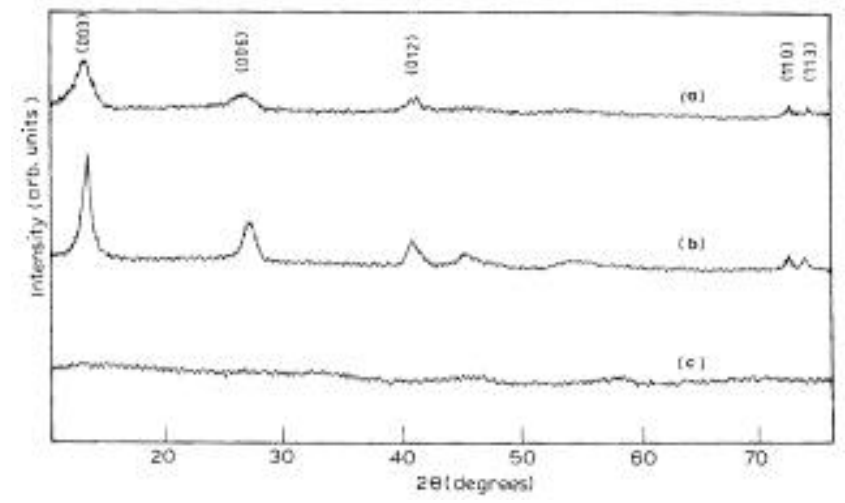

Figure 2. Powder X-ray diffraction pattern of (a) the phase precipitated during the titration of a mixed metal $(\mathrm{Mg}+\mathrm{Al})$ chloride solution compared with the products of an $\mathrm{Al}(\mathrm{OH})_{3}$ gel aged in a $\mathrm{MgCl}_{2}$ solution at (b) $\mathrm{pH}>12$ and (c) the II $\mathrm{pH}$ value. representative data obtained in the $\mathrm{Mg}-\mathrm{Fe}$ titration. However, the solids obtained at the end of titration in the $\mathrm{Mg}-\mathrm{Fe}$ and $\mathrm{Ni}-\mathrm{Fe}$ cases exhibited the formation of LDHs. On the other hand, when ' $\mathrm{Fe}(\mathrm{OH})_{3}$ ' slurries were aged in $\mathrm{MgCl}_{2}$ and $\mathrm{NiCl}_{2}$ solutions at their respective II $\mathrm{pH}$ values as well as at $\mathrm{pH}>12, \mathrm{LDH}$ formation was observed in the case of $\mathrm{Mg}$ (figure 4), but not in the case of $\mathrm{Ni}$.

The fact that the II $\mathrm{pH}$ value coincides exactly with the $\mathrm{pH}$ at precipitation of the unary divalent hydroxide shows that the material precipitated at the second plateau is the unary divalent hydroxide and not $\mathrm{LDH}$. The following questions arise: (i) why is LDH formation observed at the end of titrations? and (ii) why is LDH formation observed in aging experiments in the $\mathrm{Mg}-\mathrm{Fe}$ system but not in the Ni-Fe system? We suggest that the LDH observed in the titration products is actually formed by coprecipitation induced by a steep increase in the local $\mathrm{pH}$ due to the addition of highly concentrated base during the titrations.

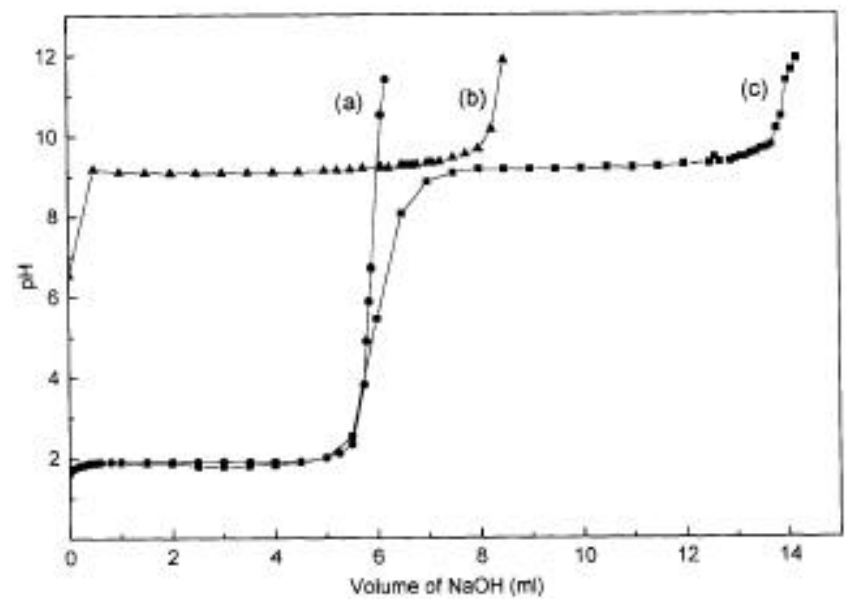

Figure 3. $\mathrm{pH}$ profiles of titration of (a) a $\mathrm{FeCl}_{3}$ solution, (b) a $\mathrm{MgCl}_{2}$ solution compared with that of the (c) mixed metal $(\mathrm{Mg}+\mathrm{Fe})$ chloride solution with $\mathrm{NaOH}$.

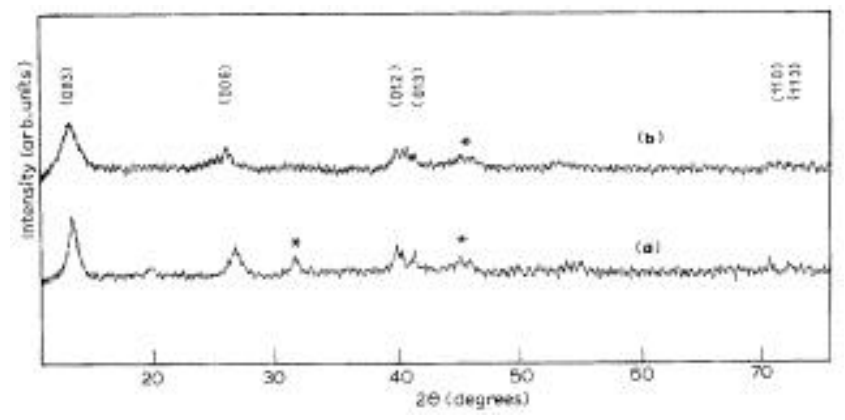

Figure 4. Powder $\mathrm{X}$-ray diffraction pattern of a $\mathrm{Fe}(\mathrm{OH})_{3}$ gel aged in (a) a $\mathrm{MgCl}_{2}$ solution at II $\mathrm{pH}$ value compared with (b) the phase precipitated during titration of mixed metal $(\mathrm{Mg}+\mathrm{Fe})$ chloride solution. Peaks marked by an asterisk are due to impurities. 
These conditions are far from equilibrium. ' $\mathrm{Fe}(\mathrm{OH})_{3}$ ' is also mildly amphoteric. The II $\mathrm{pH}$ value $(9.2)$ is high enough to cause the dissolution of ' $\mathrm{Fe}(\mathrm{OH})_{3}$ ' in the $\mathrm{Mg}-\mathrm{Fe}$ system but not in the $\mathrm{Ni}-\mathrm{Fe}$ system (7.2). Therefore, $\mathrm{LDH}$ formation is observed in aging experiments in the former by a mechanism similar to that in the Al containing systems but not in the latter.

\section{$3.3 \quad \mathrm{Ni}(I I)-C r(I I I) L D H$}

Mixed metal nitrate $(\mathrm{Ni}+\mathrm{Cr})$ titrations exhibit a single plateau suggesting a coprecipitation reaction as reported by Boclair et al (1999). However, the titrations as well as aging experiments carried out at the plateau $\mathrm{pH}$ (3.5) and high $(>12) \mathrm{pH}$, yield X-ray amorphous phases and LDH formation could not be established with certainty. Among the $\mathrm{Cr}(\mathrm{III})$ containing systems, except for the $\mathrm{Zn}-\mathrm{Cr}$ LDH (Boehm et al 1977), other Cr(III) containing LDHs form only on hydrothermal treatment of the coprecipitated slurry (Kooli et al 1995).

\section{$3.4 Z n(I I)-M^{\prime}(I I I)\left(M^{\prime}=A l, F e\right)$ systems}

In figure 5 are shown the $\mathrm{pH}$ profiles of the titrations in the $\mathrm{Zn}-\mathrm{Al}$ system. This differs from the other Al containing systems in that the second plateau is poorly defined. The $\mathrm{pH}$ in this region rises gradually from the $\mathrm{I} \mathrm{pH}$ value and the latter part of this plateau coincides with the $\mathrm{pH}$ at which $\mathrm{Zn}^{2+}$ precipitates. This behaviour is due to the proximity of the pHs at which the unary hydroxides precipitate. This situation promotes coprecipitation of the two metal hydroxides, by virtue of which the titrations yield the $\mathrm{Zn}-\mathrm{Al} \mathrm{LDH}$. The LDHs isolated before and after completion of the titration exhibit different interlayer distances (figure 6) due to the exchange of intercalated carbonates

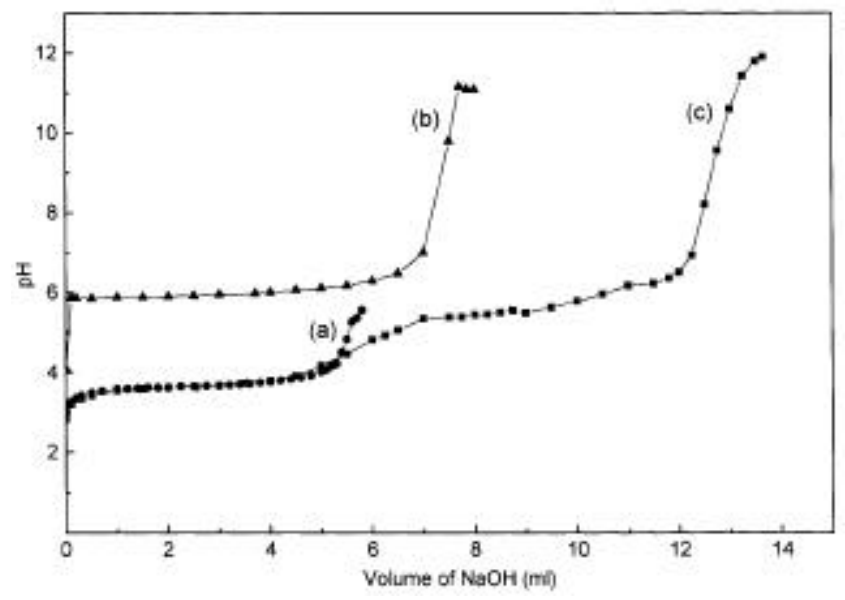

Figure 5. $\mathrm{pH}$ profiles of (a) an $\mathrm{Al}\left(\mathrm{NO}_{3}\right)_{3}$ solution, (b) a $\mathrm{Zn}\left(\mathrm{NO}_{3}\right)_{2}$ solution compared with that of the (c) mixed metal $(\mathrm{Zn}+\mathrm{Al})$ nitrate solution with $\mathrm{NaOH}$. for nitrates at high $\mathrm{pH}$. Aging experiments carried out at $\mathrm{pH} 5.6$ yield the $\mathrm{LDH}$ while at $\mathrm{pH} 12, \mathrm{ZnO}$ impurities are also observed in addition to LDH. When the aging experiment was carried out at $\mathrm{pH}>12$, only $\mathrm{ZnO}$ formation was observed (figure 7). This observation can be explained, if zinc hydroxide dehydration takes place before the dissolution of $\mathrm{Al}(\mathrm{OH})_{3}$.

The $\mathrm{Zn}-\mathrm{Fe}$ system is important, as no LDH of $\mathrm{Zn}$ with $\mathrm{Fe}$ has yet been reported. The behaviour of this system is similar to those of other Fe containing systems (figure 8) in that the II $\mathrm{pH}$ value is identical to the $\mathrm{pH}$ at precipitation of zinc hydroxide. We provide conclusive proof that no LDH formation is observed, as $\mathrm{pH}$ metric titrations of both the unary $\mathrm{Zn}$ salt as well as the mixed metal $(\mathrm{Zn}+\mathrm{Fe})$ nitrates led to the formation of the same product (figure 9) corresponding to $\mathrm{Zn}_{5}(\mathrm{OH})_{8}\left(\mathrm{NO}_{3}\right)_{2} \cdot 2 \mathrm{H}_{2} \mathrm{O}$ (PDF: 24-1460) (Smith 1967) at $\mathrm{pH}=6$. All diffraction maxima in both the patterns agree well with those reported for the zinc hydroxysalt with no evidence of Fe being incorporated in the lattice. The interlayer distance $(7 \cdot 81 \AA)$ reported by Boclair and Braterman (1999) supposedly for the $\mathrm{Zn}-\mathrm{Fe}$ LDH corresponds to $\mathrm{Zn}_{5}(\mathrm{OH})_{8} \mathrm{Cl}_{2} \cdot \mathrm{H}_{2} \mathrm{O}$ (PDF: 7-155) (Smith

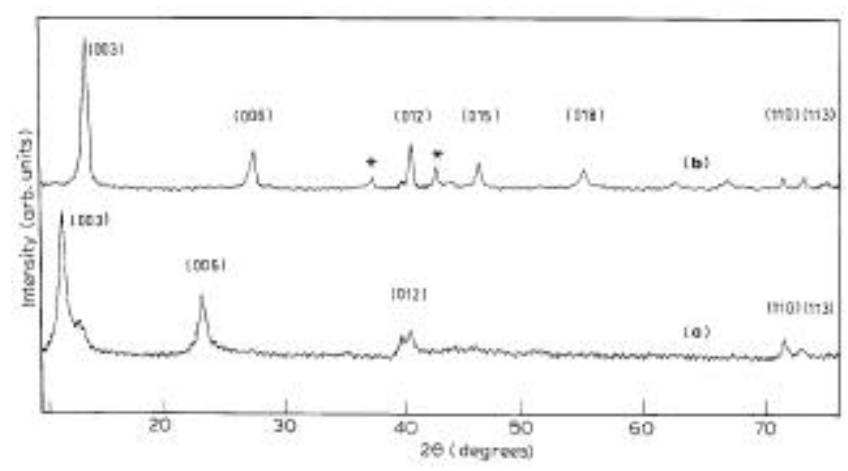

Figure 6. Powder X-ray diffraction patterns of the phases precipitated from a mixed metal $(\mathrm{Zn}+\mathrm{Al})$ nitrate solution (a) before and (b) after completion of titration. Peaks marked by an asterisk are due to impurities.

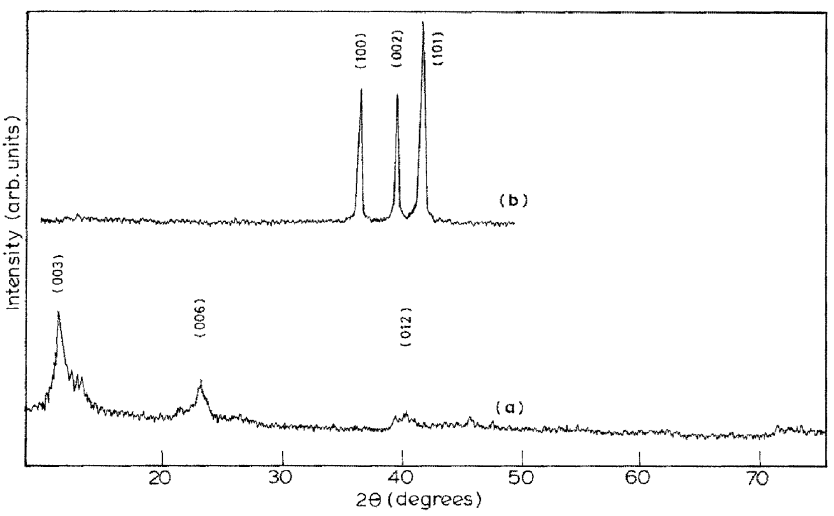

Figure 7. Powder $\mathrm{X}$-ray diffraction pattern of an $\mathrm{Al}(\mathrm{OH})_{3}$ gel aged in $\mathrm{Zn}\left(\mathrm{NO}_{3}\right)_{2}$ solution at (a) the II $\mathrm{pH}$ value and (b) $\mathrm{pH}>12$. 


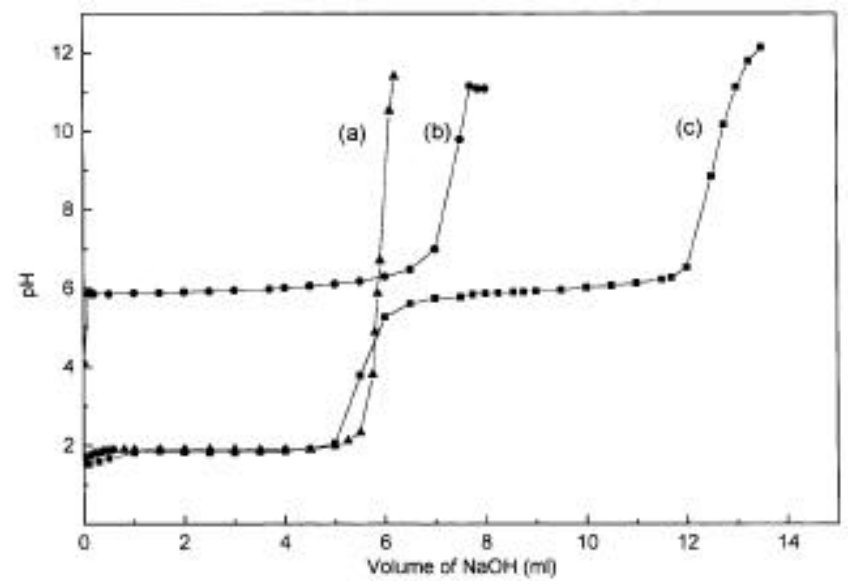

Figure 8. pH profiles of (a) an $\mathrm{Fe}\left(\mathrm{NO}_{3}\right)_{3}$ solution, (b) a $\mathrm{Zn}$ $\left(\mathrm{NO}_{3}\right)_{2}$ solution compared with that of the (c) mixed metal $(\mathrm{Zn}+\mathrm{Fe})$ nitrate solution with $\mathrm{NaOH}$.

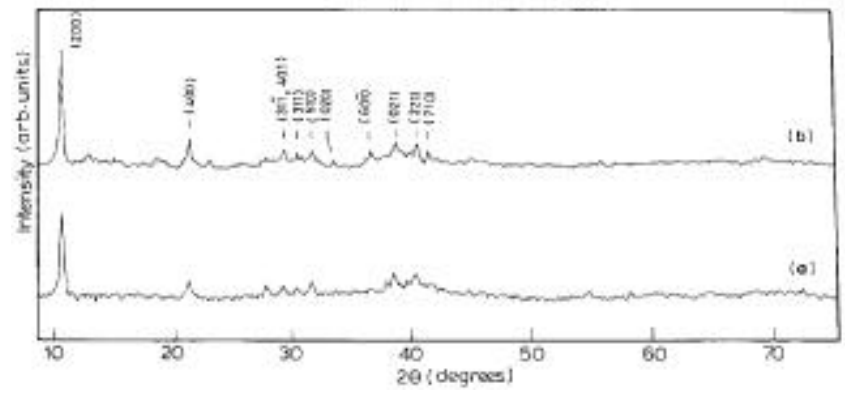

Figure 9. Powder X-ray diffraction pattern of the phase precipitated from (a) a mixed metal $(\mathrm{Zn}+\mathrm{Fe})$ nitrate solution compared with (b) that precipitated from a zinc nitrate solution.

1967). At $\mathrm{pH}>12, \mathrm{ZnO}$ formation is observed.

\section{Conclusions}

When there is a large difference in the solubility products of the trivalent and divalent metal hydroxides, LDH formation proceeds by the dissolution of the trivalent hydroxide followed by the precipitation of LDH. When the solubility products of the two unary hydroxides are close as in the case of $\mathrm{Zn}-\mathrm{Al}$ system, there is also the possibility of coprecipitation playing a major role in $\mathrm{LDH}$ formation. Caution must, however, be exercised in proposing common mechanisms for all LDHs as this family of compounds involves a diverse variety of constituents whose physical constants vary over many orders of magnitude.
(PVK) thanks the Department of Science and Technology, New Delhi, for financial support. (AVR) thanks the University Grants Commission, New Delhi, for the award of a Junior Research Fellowship (NET). Authors thank the Solid State and Structural Chemistry Unit, Indian Institute of Science, Bangalore, for powder X-ray diffraction facilities.

\section{References}

Aramendía M Á, Borau V, Jiménez C, Marinas J M, Romero F J and Urbano F J 1999 J. Mater. Chem. 92291

Boclair J W and Braterman P S 1998 Chem. Mater. 102050

Boclair J W and Braterman P S 1999 Chem. Mater. 11298

Boclair J W, Braterman P S, Jiang J, Lou S and Yarberry F 1999 Chem. Mater. 11303

Boehm H P, Steinle J and Vieweger C 1977 Angew. Chem. Int. Ed. Engl. 16265

Carrado K A, Kostapapas A and Suib S L 1988 Solid State Ionics 2677

Cavani F, Trifiro F and Vaccari A 1991 Catalysis Today 11173

Constantino V R L and Pinnavaia T J 1995 Inorg. Chem. 34883

Dobos D 1975 Electrochemical data (Amsterdam: Elsevier Scientific Publishing Company)

Grosso R P, Suib S L, Weber R S and Schubert P F 1992 Chem. Mater. 4922

Johnson C A and Glasser F P 2003 Clays and Clay Minerals 511

Kamath P V, Dixit M, Indira L, Shukla A K, Kumar V G and Munichandraiah N 1994 J. Electrochem. Soc. 1412956

Khan A I and O'Hare D 2002 J. Mater. Chem. 123191

Kooli F, Rives V and Ulibarri M A 1995 Inorg. Chem. 345122

Miyata S and Hirose T 1978 Clays and Clay Minerals 26441

Newman S P and Jones W 1998 New J. Chem. 105

Oesten R and Böhm H 1993 Solid State Ionics 62199

Oswald H R and Asper R 1977 Preparation and crystal growth of materials with layered structures (ed.) R M A Lieth (Dordrecht: D. Reidel Publishing Company) 1 p. 71

Radha A V, Kamath P V and Subbanna G N 2003 Mater. Res. Bull. 38731

Ramesh T N, Jayashree R S and Kamath P V 2003 J. Electrochem. Soc. 150 A520

Reichle W T 1986 Solid State Ionics 22135

Rebours B, d'Espinose de la Caillerie J B and Clause O 1994 J. Am. Chem. Soc. 1161707

Rives V, Labajos F M, Ulibarri M A and Malet P 1993 Inorg. Chem. 325000

Rousselot I, Taviot-Guého C, Leroux F, Léone P, Palvadeau P and Besse J P 2002 J. Solid State Chem. 167137

Smith J V (ed.) 1967 Powder diffraction file (Pennsylvania: Joint Committee on Powder Diffraction Standards)

Uzunova E L, Mitov I G and Klissurski D G 1997 Bull. Chem. Soc. Jpn. 701985

Wells A F 1979 Structural inorganic chemistry (London: The English Language Book Society and Oxford University Press) 4th ed.

\section{Acknowledgements}

